\title{
Cyclodextrin Formation Initiated by Enzyme Debranching Reaction On Amylopectin Branch Chain Of Tapioka
}

\author{
Amran Laga \\ Study Program of Food Science and Technology Faculty of Agriculture, Hasanuddin University \\ Kampus Unhas Tamalanrea, Jln Perintis Kemerdekaan km. 10, Makassar 90245 \\ Diterima 08-06-2008 \\ Disetujui 09-02-2009
}

\begin{abstract}
Degradation of starch by the glucosyltransferase enzyme (CGTase) to produce the primary product of chain splitting undergoes an intramolecular reaction without the participation of water molecule. From this process, $\alpha$ 1,4-Linked cyclic product, known as cyclodextrins, are formed. The aim of the research was to cut amylopectin branch in order to produce one straight chain, to optimize cyclic reaction formation cyclodextrin by CGTase. The research was devided into 3 stages; (1) debranching enzyme concentration estimation $(5,10,15,20$, and 25 unit/ gram) and the length of otimum reaction to produce straight chain for 5 hours which sample was taken each hour, (2) reaction length time estimation to form cyclodextrin in order to use debranching products (straight chain) as substrates, the reaction length for $\mathbf{3 6 0}$ minutes and sample taken each for $\mathbf{3 0}$ minutes, and (3) the best substrate concentration for straight chain $(20-40 \% \mathrm{w} / \mathrm{v})$ to produce cyclodextrin. The result showed that enzyme concentration treatment and optimal length reaction will produce straight chain with enzyme concentration of 14 units/gram for 3 hours and straight chain product of 20 units/gram for 1 hour with straight chain product of $83.5 \%$. The optimum length of reaction for cyclodextrin formation from amylose produced from the de-branching process was 240 minutes. The amount of cyclodextrin produced was $143.45 \mathrm{~g} / \mathrm{L}$ with conversion value of $47.81 \%$ at $30 \%$ (w/v) substrate concentration. Highest yield of cyclodextrin $(154,28 \mathrm{~g} / \mathrm{L})$ and conversion value of $44.08 \%$ was obtained at $35 \%(w / v)$ substrate concentration.
\end{abstract}

Keywords: amylopectin, debranching, CGTase, cyclodextrin

\section{INTRODUCTION}

Cyclodextrin is oligosaccharide product nonreduction of modified starch with ring-formation and made through cycling reaction by CGTase activation (Cyclodextrin glycosil transferase) (Szejtli, 1988; Schmid, 1989; Tankova, 1998). Based on glucose formation, cyclodextrin was divided into: $\alpha$-siklodekstrin (6 unit glucose), $\beta$-siklodekstrin (7 unit glucose) dan $\gamma$ siklodekstrin (8 unit glucose) (Szejtli, 1988 \& Tankova, 1998). Cyclodextrin with ring formation can be seen at Figure 1.

CGTase mechanism is to catalyze cyclodextrin formation according to Schmid (1988) which started by 8-10 formation (or more than glucose number that formed cyclodextrin) glucose unit of starch molecules. The reaction is strated from glucose branch from nonreduction. Cyclodextrin has unique characteristics, which can be used in such industries as pharmacy, cosmetics, food, flavour, agriculture and chemical industries (Szejtli, 1988).

\footnotetext{
*Telp: +6281342665494

Email: amranlaga@yahoo.co.id
}

Tapioca is one of starch source to be used as cyclodexrin production. Tapioca contains high content of amylopectin $82-84 \%$ (Laga, 2008). High amylopectin caused limitation of tapioca usage as substrate to produce cyclodextrin. High amylopectin content will cause high pasta viscosity and also low CGTase activity towards branch chain. This caused by CGTase cycle activity on straight chain molecules (amilosa) is relatively higher compared to branch chain molecule (amylopectin) (Whistler et al., 1984).

Therefore, to optimize cyclodextrin formation from tapioca, amylopectines straight chain components needed to be cut as small chains before CGTase addition for cycle process to form cyclodextrin. The branch cutting of side chain branch $(\alpha-1.6)$ can produce straight component, lower pasta viscosity. This research was done to: (1) branch cutting of amylopectin to produce optimize straight chain catalyses by CGTase in cyclodextrin production, (2) know the length of time for cyclodextrin reaction to utilize the debranching products as substrates, (3) optimize substrate concentration estimation in the cyclodextrin production. 


\section{METHODS}

Materials and Equipments. Materials used for the research were of pullulanase and CGTase (Toruzyme $^{\text {TM }}$ 3,0 L) from Novo Nordisk, tapioca flour, soluble starch, glucose standard, amylose standard, Phenolic 5\%, DNS, $\mathrm{H}_{2} \mathrm{SO}_{4} \mathrm{NaOH} 0,1 \mathrm{~N}$, lod, KI, KaliumNatrium Tartrat, $\mathrm{Pb}$ asetat, $\mathrm{CaCl}_{2}$ and $\mathrm{CaCO}_{3}$.

Equipments used were shaker incubator (Barnstead/Lab-line Max ${ }^{\circ} 4000$ ), spektropho tometer (UV/VIS spectrophotometer SP-3000 Plus OPTIMA JAPAN), pH meter (Dakton pH 510 Series), micropipet (Eppendorf Adjustable Volume Pipettors), sentrifugator (Heraeus Labofuge A), hot plate (Hot plate Stirerrer CB 302 Stuart), oven (Memmert) and glasswares.

Procedure. The research was devided into 3 stages; (1) enzyme debranching concentration estimation and the length of optimum reaction to produce straight chain for 5 hours which sample was taken each hour, (2) reaction length time estimation to form cyclodextrin in order to use the debranching products (straight chain) as substrates, and (3) the best substrate concentration for straight chain to produce cyclodextrin.

Concentration debranching enzyme (pullulanase) and optimum reaction time to produce straight chain. The research started by making tapioca starch for $40 \% \mathrm{w} / \mathrm{v}$ concentration, added $\mathrm{Ca}^{2+}\left(\mathrm{CaCl}_{2}\right)$ for $12 \mathrm{ppm}$ and acidity degree on $\mathrm{pH} 5$. Suspension were then distributed in the flasks $250 \mathrm{~mL}$ with volume $150 \mathrm{~mL}$. Pullulanase were then added onto suspension for $10,15,20$, and 25 (unit/g substrate). Suspension were then heated or gelatinized with stirred to achieve $75^{\circ} \mathrm{C}$, then the temperature was then cooled to $50^{\circ} \mathrm{C}$. The reaction was maintained at $50^{\circ} \mathrm{C}$ for 5 hours and sample was taken every one hour.

The parameter observed was amilosa value (as straight chain) IRRI methods (1971) and amylopectin value from starch differences with the lowest amilosa value (Apriyantono et al., 1989). The data was done in 2 variables, variable $A$; enzyme concentration and variable $B$ was reaction time length. The experiment was done in 2 replicates. If there are differences in between, data were further analyzed with BNJ test.

Reaction length time estimation to form cyclodextrin in order to use debranching products (straight chain) as substrates. Debranching substrate (straight chain) preparation was done by enzyme concentration treatment and the best time length produced at the first stage. Debranching product which

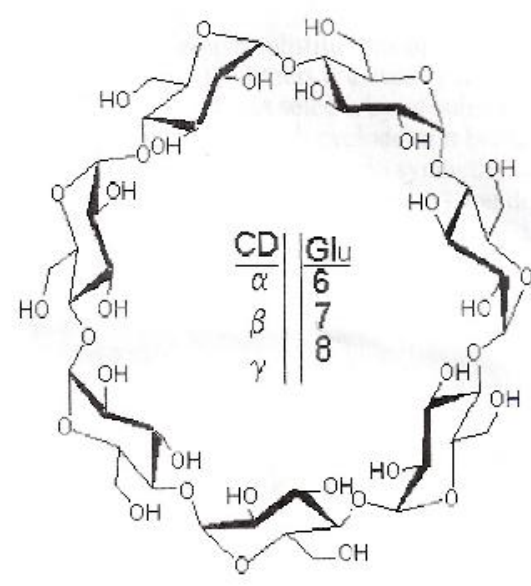

Figure 1. Structures of â-cyclodextrin (Szejtli et al, 1988)

was done by adding some substrate with $30 \% \mathrm{w} / \mathrm{v}$ concentration. Substrate was then suspended into phosphat buffer pH $6(0.2 \mathrm{M})$ then CGTase 100 unit/ gram was added onto substrate and ethanol $10 \%(\mathrm{v} / \mathrm{v})$. The ethanol usage was to prevent reversed reaction (Blackwood \& Bucke, 2000). The reaction was done in shaker incubator at $60^{\circ} \mathrm{C}$ with the stirrer speed of 200 rpm for 360 minutes. The sample was taken every 30 minutes.

The parameter observed including cyclodextrin Kitahata method (1988), reduction sugar (DNS method), and conversion value. The research was done by experimental method with 3 times repetition. The best temperature and time length was estimated by data plotting.

The best Substrate concentration estimation of straight chain on cyclodextrin formation. Substrate debranching (straight chain) preparation was done by using enzyme concentration treatment and the best reaction time length which was gained on the first treatment. The debranching product was used as base product which concentration of substrate of; 20 , $25,30,35$ and $40 \% \mathrm{w} / \mathrm{v}$.

The debranching product was then suspended on phosphate buffer $\mathrm{pH} 6(0.2 \mathrm{M})$, then CGTase was added $100 \mathrm{unit} / \mathrm{gr}$ of substrate and ethanol $10 \% \mathrm{v} / \mathrm{v}$. The reaction was done in shaker incubator at $60^{\circ} \mathrm{C}$ with the stirrer speed of $200 \mathrm{rpm}$ for 360 minutes. The length of reaction of sample was taken from the best result of second stage experiment.

The parameter observed including cyclodextrin Kitahata method (1988), reduction sugar (DNS method) and conversion value. The research was done by experimental method with 2 times repetition. If there 
were any significat result showed, the data was then analyzed with BNJ test.

\section{RESULT AND DISCUSSION}

Pullulanase concentration estimation and Optimized Debranching time length on Straight Chain formation (Amylose). Amylopectin. The amylopectin result showed that during dibranching reaction, the higher enzyme concentration (5-25 unit/ gram), the lower amylopectin concentration (Figure 2). The longer debranching reaction, (1-5 hours) showed the decreasing amylopectin value (Figure 2). Debranching enzyme is a specific enzyme that cut $\alpha$ 1.6 D-glycosidic of amylopectin (strach), glicogen and pullulan (Hamilton et al., 2000).

Statistical analysis indicates that enzyme concentration, length of reaction and its interaction significantly affect the breakdown of side branch. Further analysis on the effect of the interaction indicates debranching was optimal at 15 units of enzyme concentration with reaction time of 3 hours. Under these conditions, the residual amylopectin was $16 \%$. The use of 20 units enzyme concentrtation resulted in 16.5\% residual amylopectin with 1 hour of reaction time. These values indicate that the debranching of amylopectin under the above conditions was relatively efficient with the degree of hydrolysis reached $80 \%$ and $79.37 \%$ of the total amylopectin initially present in the substrate. This is in accordance with the opinion of Vasanthan \& Bhatty (1996) who indicated that the efficiency of a reaction can be measured based on substrate reduction during reaction.

Amylose. The result from analysis of straight chain (amylose) from enzyme concentration treatment, showed that pullulanse usage with concentration of 5 unit/gram with straight chain resulted realtifity small

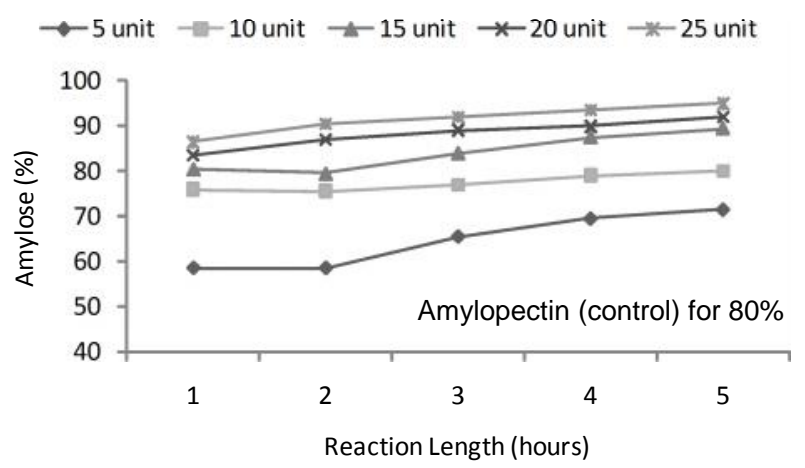

Figure 2. Amylopectin change pattern of tapioca starch of enzyme concentration and enzyme reaction with the average of $64.7 \%$ during debranching for $1-5$ hours (Figure 3 ). The increasing of enzyme concentration for 10, 15, $20 \& 25$ unit showed straight chain increasing by $77,5 \%, 88,2 \%, 88,3 \%$ and $91,5 \%$ respectively. BNJ test results between enzyme concentration showed the significance differences from one to another except 15 and 20 unit/gram was not significant.

The reaction length showed the reaction time from 1, 2, 3, 4 and 5 hour were tend to increase straight chain products of $77 \%, 78,2 \% 81,5 \%, 83,9 \%$ and $85,6 \%$ respectively. Significant test showed one treatment to the other was significant, except for 1 and 2 hours was not dignificant.

The straight chain reaction (amylose) from different interaction of enzyme concentration for reaction time, showed optimized treatment for enzyme concentration for 15 unit/gram with the reactiion time of 3 hours and enzyme consentration for 20 unit/gram for 1 hour. Straight chain reaction from both combination for both treatments each for $84 \%$ and $83,5 \%$.

Debranching reaction resulted amylopectin components from pullulanase reaction were straight chain componen (amylose). According to Yakobayashi (1988), that debranching enzyme hydrolise starch the of $\alpha-1.6$ glicosidic chain of starch (amylopectin) or glycogen and result straight chain of amylose as below:

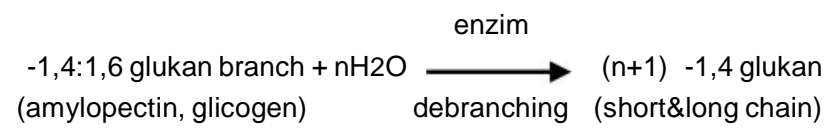

Amylose component is a polimer arranged from glucose monomer, one of glucose unit among one another connected from $\alpha-1.4$ to form straight chain (Whisler \& Daniel, 1985). Amylose polimerized degree from 500-5000 (Doelle et al., 1992; Klucinec et al., 1999). Amylopectin components have side chains for $\alpha-1.6 \mathrm{D}$ glikosidic, the length of the chain are 20-25 unit glucose, from one another that connected by $\alpha$ 1.4 D glikosidic (Pomeranz, 1985).

The length of reaction estimation of optimized cyclodextrin by using debranching products as substrate. Debranching product usage as substrate from the beginning of reaction until 90th minute, showed cyclodextrin formation relatively small, $15.55 \mathrm{~g} / \mathrm{L}$ at 30 minutes and $31.96 \mathrm{~g} / \mathrm{L}$ at 90 minutes. On the same time, big amount of reduction sugar of $19,55 \mathrm{~g} / \mathrm{L}$ at 30 minutes and $32,35 \mathrm{~g} / \mathrm{L}$ at 60 minutes (Figure 4). 

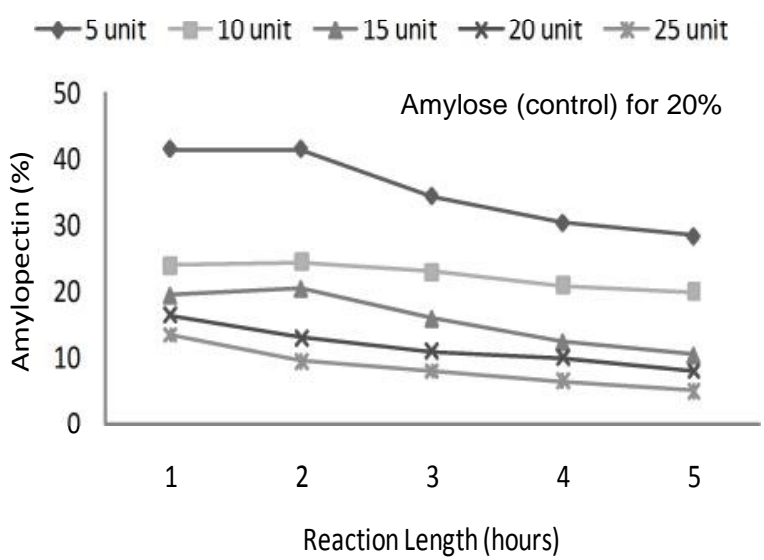

Figure 3. Amylose formation pattern of topioca starch of enzyme concentration and enzyme reaction.

The phenomena caused by cyclic process at cyclodexrin formation from debranching units products with relatively short chain. The average of each branch chain of tapioca amylopectin was around 20-25 units of glucose (Pomeranz, 1985). $\beta$-siklodekstrin (7 units glucose) making process of branch units chain may undergo cyclic process 2-3 times, short chain components could not be cycled. Short chain fragments would not raised reduction sugar contents on medium.

Cyclodextrin formation on bigger form at 150 to 240 minutes $(101,35-143,45 \mathrm{~g} / \mathrm{L})$ at the same time with reduction sugar may increase even small amount (Figure 4). The phenomena showed at the particular timelength, the formation of cyclodextrin formed from starch molecules (the main branch), which will form relatively small fragments of reduction sugar. The particular condition may trigger CGTase activity on one direction, therefore cyclic reaction formation could be optimized.

Cyclodextrin achieved after 240 minutes reaction time tend to decrease, on 270 minutes for $141,65 \mathrm{~g} / \mathrm{L}$ and 360 minutes for $138,77 \mathrm{~g} / \mathrm{L}$. Decreasing cyclodextrin condition, reduction sugar, and conversion value were constant (Fig 4). The decreasing was tend to happenned of cyclodexrin was at 240 minutes, will caused reaction of disproporsionation before cyclic reaction happenned.

Disproporsionation reaction was one of CGTase activities to connect the small chains to be long chains. According to Schmid (1989), if disproporsionation long chain optimized, then CGTase cyclic reaction happenned. Cyclodextrin resulted from the beginning of substrate from G2 (maltosa) and G3 (maltotriosa) at certain time will be reduced. It happens due to characteristics of G2 and G3 as aceptor that caused cyclodextrin easily decomposed (Kitahata, 1988).

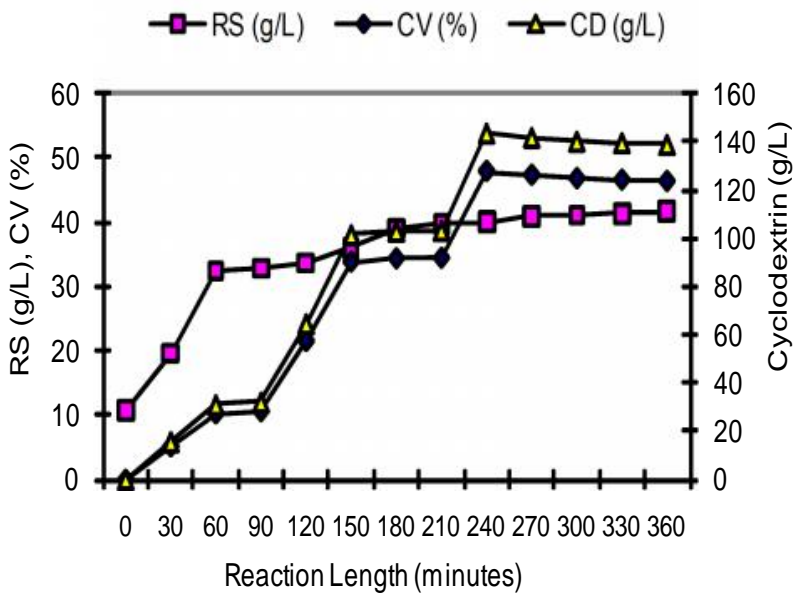

Figure 4. Profile of reduction sugar (RS) invertion, cyclodextrin $(\mathrm{CD})$, and conversion value (CV) through the reaction.

The result of analysis during the reaction showed that the highest cyclodextrin (143,45 g/L) achieved at 240 minutes reaction time with conversion value of $47,81 \%$ on substrate usage of $30 \% \mathrm{w} / \mathrm{v}$. For that reason, the second stage of experiments was conducted.

The best estimation of Straight Chain substrate concentartion for Cyclodextrin formation. The best debranching sugar concentration estimation to produce cyclodextrin was done using the best treatment from first stage and second. The treatment used for debranching process was pullulanase enzyme usage for 20 unit/gram with 1 hour reaction time. On the production stage, cyclodexrin time to optimize the reaction was 240 minutes.

Reduction sugar value and Dextrose Equivalent. The purpose of reduction sugar analysis was to find out the total reduction sugar during cyclodexrin formation, since reduction sugar on certain concentration could inhibit cyclodexrin formation. Chemical analysis on samples during reaction reveals that the increase in substrate concentration tends to increase the formation of reduction sugar (Fig. 5). Therefore, there is a direct relation between the production of cyclodextrin and the formation of reduction sugar as a side product of the process.

Dextrose equivalent (DE) value tends to fluctuate as subsrate concentration was increased. At $20 \%$ (w/ v) substrate concentration, DE value was $15,89 \%$ while at $25 \%$ and $30 \%(\mathrm{w} / \mathrm{v})$ the DE value decreased to $13,96 \%$ and $13,32 \%$ respectively. Increasing substrate concentration further to $35 \%$ and $40 \%(\mathrm{w} / \mathrm{v})$ resulted in an increase the DE value to $17,55 \%$ and $18,99 \%$.

Starch cyclic activity for formation of cyclodextrin will result in short chain components that may not be 
converted to cyclodextrin. Short chain accumulation will further result in the increasing of sugar reduction value. According to Kitahata (1988) \& Tankova (1998), cyclodextrin formation from substrate (starch or maltoligosaccharides) through cyclic reaction CGTase formed simple sugar (short chain molecules).

Cyclodextrin and conversion value. Analysis on cyclodextrin yield suggested that the yields tend to vary based on substrate concentration. Increasing substrate concentration tended to increase cyclodextrin yields. An exception to this is the yield obtained at $40 \%(\mathrm{w} / \mathrm{v})$ substrate concentration which was slightly lower than the yield obtained at $35 \%(\mathrm{w} / \mathrm{v})$ substrate concentration. Conversion of substrate into cyclodextrin also indicated the same trend (Fig. 6). Under the experimental condition employed, the highest cyclodextrin yield $(154.28 \mathrm{~g} / \mathrm{L})$ was obtained at $35 \%$ $(\mathrm{w} / \mathrm{v})$ substrate concentration. The corresponding conversion value was $44.08 \%$. On the other hand, the highest conversion value $(47.82 \%)$ and the corresponding cyclodextrin yield of $143.45 \mathrm{~g} / \mathrm{L}$ was obtained at $30 \%(\mathrm{w} / \mathrm{v})$ substrate concentration. These results reveal that, with respect to the degree of conversion, the use of de-branching product as substrate for cyclodextrin production was optimum at $30 \%(w / v)$ concentration. However, for maximum cyclodextrin yield, the concentration can be increased to $35 \%(\mathrm{w} / \mathrm{v})$.

Higher substrate concentration of $40 \% \mathrm{w} / \mathrm{v}$ caused lower formation of cyclodextrin. It shows that substrate concentration above $35 \% \mathrm{w} / \mathrm{v}$ was not efficient. The phenomena shows that substrate concentration above $35 \%$ as the enzyme steady state concentration. Vasanthan \& Bhatty, (1996), previously indicated that low substrate concentration can lower overall enzyme

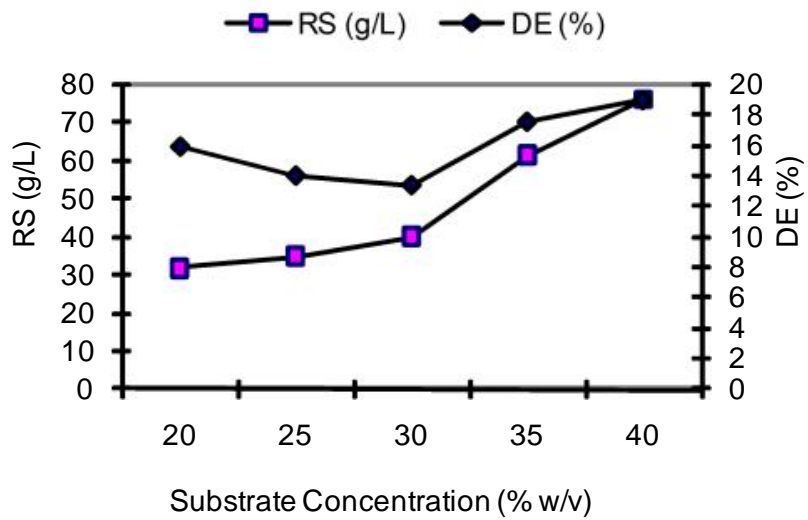

Figure 5. Substrate concentration relationship towards reduction sugar (RS) and dextrose equivalent (DE) of cyclodextrin formation reaction activity since there is a lack of substrate for the active site of the enzymes to attach to. Consequently, the enzymes compete for the available substrate thus reducing their activity. On the other hand, excessively high substrate concentration can hinder conversion process thus reducing the yield of the final product.

Other factors causing the decrease in the cyclodextrin produced at $35 \%(\mathrm{w} / \mathrm{v})$ substrate concentration were the increase in the viscosity of the feed and the increase in the formation of reduction sugar. The increase in the feed viscosity can act to decrease the interraction between enzymes and substrates, thus reducing the rate of cyclization reaction. This is in accordance with what has been suggested by Lee \& Kim, (1991), who suggested that enzymatic reaction is difficult at high starch concentration since suspension viscosity can significantly increase during liquefaction process. In addition, at high substrate concentration, initial reduction sugar concentration in the feed is relatively high which can act as an acceptor that partially inhibit cyclization reaction in cyclodextrin formation. In this case, reduction sugar can act as an acceptor whenever DE value exceeded $20 \%$. Under this condition, the reduction sugar can induce coupling reaction which will open-up the cyclodextrin structure followed by disproporsionation process. The net result is a decrease in cyclodextrin yield (Schmid, 1989).

It is evident from the above results that the use of high concentration substrate tend to decrease cyclodextrin yield. This phenomenon is similar to findings reported by Mattsson et al., (1991), which indicate reduction in conversion (from $70 \%$ to $48.83 \%$ ) when substrate concentration was increased to $30 \%$. The same phenomenon was also reported by Lee \& Kim (1991) from their work using non-liquefied corn

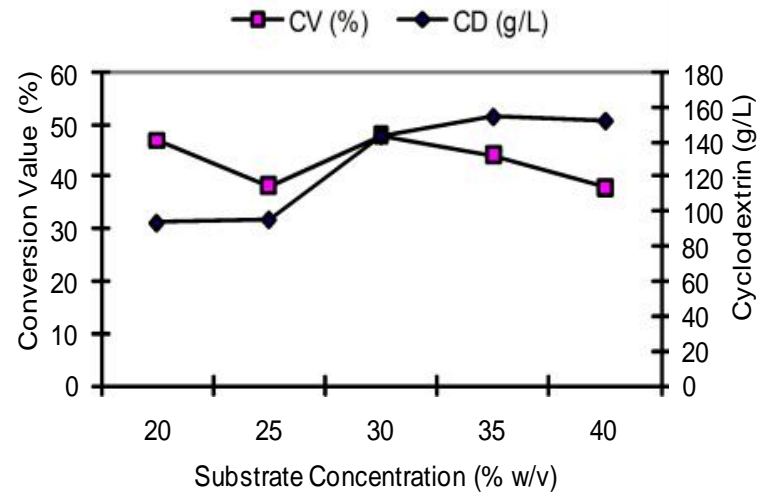

Figure 6. The relationship between substrate towards cyclodextrin and conversion value 
starch. In their work, maximal cyclodextrin yield of 50 $\mathrm{g} / \mathrm{L}$ was achieved when using $15 \%$ substrate concentration; slightly higher than the yield obtained at $20 \%$ substrate concentration.

\section{CONCLUSION}

The de-branching of tapioca using pullulanase was optimal at 15 unit/g enzyme concentration and reaction time of 3 hours. Under this condition, the degree of hydrolysis was $84 \%$. At 20 unit/g enzyme concentration, the degree of hydrolysis achieved was down to $83.5 \%$ with one hour reaction time.

The optimum length of reaction for cyclodextrin formation from amylose produced from the de-branching process was 240 minutes. The amount of cyclodextrin produced was $143.45 \mathrm{~g} / \mathrm{L}$ with conversion value of 47.81 $\%$ at $30 \%(w / v)$ substrate concentration. Highest yield of cyclodextrin $(154,28 \mathrm{~g} / \mathrm{L})$ and conversion value of $44.08 \%$ was obtained at $35 \%(\mathrm{w} / \mathrm{v})$ substrate concentration.

\section{ACKNOWLEDGEMENT}

This research was funded by a Research Grant (Riset Fundamental) provided by Directorate of Research and Extension, Directorate General of Higher Education, Ministry of National Education.

\section{REFERENCE}

Apriyantono, A.D., Fardiaz, N.L., Puspitasari, Sendarwati, \& Budiyanto, S. 1989. Analisis Pangan. Departemen Pendidikan dan Kebudayaan Direktorat Jenderal Pendidikan Tinggi Pusat Antar Universitas Pangan dan Gizi. Bogor: Institut Pertanian Bogor.
Blackwood, A.D. \& Bucke, C. 2000 . Addition of polar organic solvents can improve the product selectivity of cyclodextrin glycosyl transferase solvent effects on CGTase. J. Enzime and Microbial Technol 27: 704-708.

Doelle H.W., Mitchell, D.A., \& Rolz, C.E. 1992. Solid Substrate Cultivation. London: Elsevier Applied Science.

Hamilton, L.M., Kelly, C.T., \& Fogarty, W.M. 2000. Review: Cyclodextrin and their literation with amylolytic enzymes. J. Enzymes and Miro bial Technol 26: 561-567.

Kitahata, S. 1988. Cyclomaltodextrin glucanotransferase. Di dalam: The amylase research soceity of Japan (ed). Handbook of amylases and related enzymes. Oxford: Pergamon Press. Halaman 154-163.

Kluicinec, J.D. \& Thompson, D.B. 1999. Amylose and Amylopectin Interact in Retogradation of Dispersed HighAmylose Starch. J. Cereal Chemistry 76: 282-291.

Laga, A. 2008. Modifikasi Tapioka dengan Proses Likuifikasi Secara Enzimatis. J. Penelitian Teknologi. INTEK, Informasi Teknologi 14(1): 82-91.

Lee, Y.D. \& Kim, H.S. 1991. Enzymatic production of cyclodextrin from unliquefied corn starch in an Attrition Bioreactor. J. Bio technol. and Bioeng 37: 795-891.

Mattsson, P.T., Korpela, Pavilainen, S. \& Makela, M. 1991. Enhanced conversion of starch to cyclodextrin in ethanolic solutions by Bacillus circulan var alkalophilus cyclomaltodextrin glucano transferase. App. Bichem. and Biotechnol 30: 17-28.

Pomeranz, Y. 1985. Fungsional properties of food component. Sydney: Academic Press, Inc.

Schmid, G. 1989. Cyclodextrin glycosyltransferase production: Yield Enhancement by Overexpression of Cloned Genes. TIBTECH 7: 244-247.

Szejtli, J. 1988. Cyclodextrin technology. Dordrecht: Kluwer Academic Publish ers.

Tankova, A. 1998. Bacterial cyclodextrin glucanotransferase. J. Enzime and Microbial Technol 22: 678-686.

Vasanthan, T. \& Bhatty, R.S. 1996. Physicochemical properties of small and large granula starches of waxy, regular and high amylose barleys. Cereal Chem 73: 199.

Whistler, R.L., Bemiler, J.N., \& Paschall, E.F. 1984. Starch: Chemistry and technology (2nd edition). New York: Academic Press. Inc.

Whisler, RL. \& R. Daniel. 1985. Carbohydrates Di dalam OR Fenenema (ed.) Food Chemistry. Marcel Dekker, Inc. New York.

Yokobayashi, K. 1988. Isoamylases (Pseudomonas amyloderamosa). Di dalam: The amylase research society of Japan(ed). Handbook of amylases and related enzymes. Oxford: Pergamon Press. Halaman 125-130. 